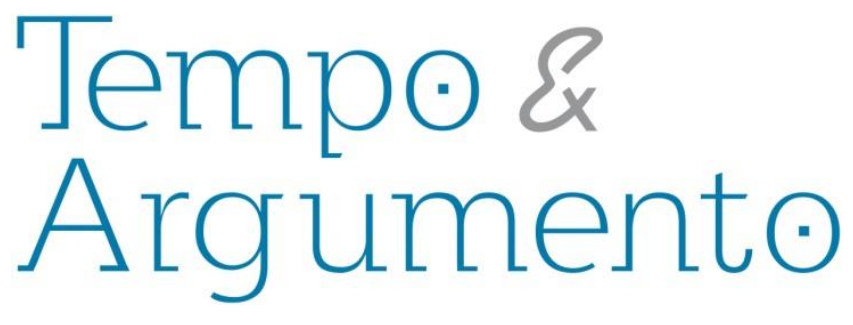

\title{
Imprensa negra e combate ao racismo (Florianópolis, 1914-1925)
}

\begin{abstract}
Resumo
O presente texto desenvolve análise crítica a respeito da produção e difusão da chamada imprensa negra em Florianópolis nas décadas seguintes à Abolição. Essa ferramenta de comunicação e divulgação compunha estratégia de mobilização de diferentes intelectuais de origem africana preocupados com o combate ao racismo, dimensionando o acesso à educação como meio de ascensão social e instrumento capaz de transformar as desigualdades raciais da sociedade da época. Com base em periódicos da imprensa local e regional, em Estatutos e Atas de associações, mapeamos movimentos de diferentes atores sociais na capital catarinense, em busca de espaços de escolarização, de sociabilidades, de inserção política e cultural. Ancorados em teóricos do campo da cultura da memória e da imprensa, organizamos nossa análise a partir das perspectivas de Taylor (2013), Connerton (1999) e Cruz e Peixoto (2007). Tais teóricos permitem um olhar a respeito das fontes utilizadas, produto de fazeres de intelectuais, "homens de cor letrados", entre 1914 e 1925, sinalizando formas de mobilização e organização no intento de apontar problemas sociais e os impactos do racismo.
\end{abstract}

Palavras-chave: História. Imprensa Negra. Florianópolis. PósAbolição.

\author{
Karla Leandro Rascke \\ Doutora em História pela Pontifícia \\ Universidade Católica de São Paulo (PUC/SP). \\ Professora na Universidade Federal do Sul e \\ Sudeste do Pará (UNIFESSPA). \\ Marabá - PA - Brasil \\ karlaleandro@gmail.com
}

\section{Para citar este artigo: \\ RASCKE, Karla Leandro. Imprensa negra e combate ao racismo (Florianópolis, 1914-1925). Tempo e Argumento, Florianópolis, v. 10, n. 25, p. 38 - 65, jul./set. 2018.}

DOI: $10.5965 / 2175180310252018038$

http://dx.doi.org/10.5965/2175180310252018038 


\title{
Black press and fight against racism (Florianópolis, 1914-1925)
}

\begin{abstract}
This text develops a critical analysis regarding the production and diffusion of the so-called black press in Florianópolis in the decades following the Abolition. This communication and dissemination tool comprised a strategy to mobilize different intellectuals of African origin who are concerned with combating racism, dimensioning access to education as a means of social ascension and an instrument capable of transforming the racial inequalities of the society of the time. Based on newspapers produced by these intellectuals, between 1914 and 1925, we developed this narrative research, pointing out strategically signaling ways of mobilizing "literate men" in an attempt to point out social problems and the impacts of racism. Based on local and regional press periodicals, Statutes and Minutes of associations, we mapped movements of different social actors in the state capital, in search of spaces of schooling, sociabilities, political and cultural insertion. Anchored in theorists of culture, memory and press, we organize our analysis from the perspective Taylor (2013), Connerton (1999) and Cruz and Peixoto (2007). Such theorists allow us to look at the sources used, produced by these intellectuals "literate men of color", between 1914 and 1925, we developed this research, signaling forms of mobilization of "literate men", and organization in the attempt social problems and the impacts of racism.
\end{abstract}

Keywords: History. Black Press. Florianópolis. Post-Abolition.

\section{Introdução}

Pensar a imprensa negra requer discutir implicações e objetivos desse tipo de documento para uma época, analisando-o enquanto fonte histórica. A imprensa, de um modo geral, demanda pensarmos que os discursos por ela veiculados não são neutros, tampouco isentos, compreendendo que para circulação de novos números, cada exemplar vendido significa recursos para manutenção da equipe redatora e dos custos envolvidos nesse tipo de produção. 
No caso da imprensa negra, não podemos reduzir as expectativas políticas da população negra no início do século XX aos jornais dessa vertente, mas, compete perceber que muitos debates e os envolvidos nessas folhas discutiam questões pertinentes e articuladas à "reflexão crítica sobre a passagem de escravo a cidadão negro. O que havia mudado? O que poderia mudar? Eram questionamentos centrais da época" (GOMES, 2005, p. 29). Em diferentes contextos e territórios, percebe-se que muitos periódicos tinham como preocupação denunciar situações de racismo, segregação, pobreza, falta de oportunidades, ausência de políticas para as populações recém-saídas da escravidão.

Analisando a imprensa negra em São Paulo, Flávio Gomes (2005) destaca que estes periódicos eram instrumentos de comunicação de "inúmeros intelectuais, grupos, associações e entidades negras", procurando estimular, através de editoriais e de determinados artigos, "temas que abordassem a autovalorização da população negra, sua visão de mundo e suas formas políticas, culturais e religiosas de organização e participação" (GOMES, 2005, p. 31). Para o autor, essas folhas, produzidas em grande parte com apoio de clubes literários, cívicos e recreativos, tinham financiamento próprio, contando inclusive com campanhas de manutenção e reprodução de seus números.

Em relação a Florianópolis, pouco se tem pesquisado a respeito dessa produção literária negra em forma de jornais e revistas, vinculadas ou não a associações literárias, clubes recreativos ou centros cívicos. Em grande medida, isso se deve a escassez de fontes existentes do que se chamaria imprensa negra na cidade. Além disso, "nem sempre os folhetins falam a um público negro, e também, nem sempre as expressões usadas pelos veículos impressos dimensionam essa politização esperada para homens e mulheres de cor" (RASCKE, 2018, p. 119). Em alguns momentos isso fica latente, não explícito, o que difere bastante de realidades como São Paulo e Rio Grande do Sul, por exemplo, onde inúmeras sociedades recreativas, literárias e cívicas organizaram periódicos significativamente direcionados, com caráter educativo aos seus associados.

Nosso intento, diante dessas "advertências" iniciais, abrange compreender elementos da produção de periódicos da imprensa negra em Florianópolis, em especial a Folha Rosea, A Urucubaca, O Literato e o XXIX de Maio, materiais com poucos exemplares, 
ou apenas um exemplar, localizado(s) no setor de Obras Raras da Biblioteca Pública do Estado de Santa Catarina (disponíveis on-line em: <http://hemeroteca.ciasc.sc.gov.br/ jornais >). Até algumas décadas atrás, a historiografia catarinense, e a dita nacional, desconheciam a produção literária de afrodescendentes no pós-abolição. E isso incluía os periódicos produzidos nas décadas seguintes à Abolição.

Analisar documentos sobre presença de matrizes de origens africanas em Florianópolis exige compreender registros confeccionados em diferentes suportes e, quando em baluartes ocidentais, como é o caso da imprensa, lê-los na contramão da hegemonia dos padrões estéticos do seu formato de produção. Práticas e resistências dessas populações em registros de imprensa, com peculiaridades, linguagem constitutiva do social, demandam análise de acordo com a historicidade na qual foram produzidos. Pautamo-nos em orientações de Peixoto e Cruz (2007), no que tange aos cuidados necessários na análise deste tipo de documentação, visto ser produzida numa determinada conjuntura, com propósitos específicos, e permeada por seu espaço social.

\section{Notas sobre a cidade de Florianópolis e relações raciais}

O projeto de construção de uma identidade nacional, aliado à educação, possuía diferentes frentes a compor o ideal modernizador e civilizatório em projeção. As cidades, sobretudo as capitais, receberam cuidados especiais em termos estéticos, higiênicos e urbanos. O esquadrinhamento de Florianópolis, em especial de seu perímetro urbano, área central da cidade, vivenciou novo projeto e traçado reformulado pela República, por intenções embasadas em controle sobre espaços e condutas.

Bairros como Figueira, Pedreira, Tronqueira, Campo do Manejo e Cidade Nova possuíam, como uma de suas marcas, a concentração de populações de origem africana, resquícios da antiga escravidão urbana, dos trabalhos desenvolvidos por essas populações e por seus aluguéis nessa área mais central da cidade (CARDOSO, 2008). Tais regiões, como salienta Santos (2009), foram impactadas por transformações e reformulações, processo que expulsou, de diferentes formas, os populares de origem africana dessas áreas, em especial, culminando na formação das adjacências do centro, os contornos dos morros. 
Bondes puxados à tração animal, uma ilha "isolada" do continente por não possuir ponte, problemas com a infraestrutura básica, iluminação pública em apenas algumas regiões, poucas áreas com água encanada, formação de novos territórios após a Abolição, reconfiguração e expulsão em razão de inúmeros impostos e exigências municipais que a população empobrecida e de origem africana estava impedida de arcar, além de processos migratórios de regiões e municípios no entorno de Florianópolis, compunham cenas cotidianas de uma cidade em movimento, mas cujos ideais de progresso não seriam alcançados por todos, em especial porque esses projetos não eram para todos. A principal avenida, símbolo do progresso almejado pelas elites governantes, a Avenida do Saneamento, hoje Avenida Hercílio Luz, findou com o rio utilizado pelas lavadeiras, bem como expulsou daquela área a presença de outros trabalhadores que viviam em torno do Rio da Bulha (DALLABRIDA, 2001).

Em termos populacionais, Florianópolis possuía alguns dados que merecem nossa atenção: em 1890, segundo Cardoso e lanni (1960, p. 93), havia 8.153 brancos, 928 pretos, 1.957 mestiços e 53 caboclos, para o que seria o perímetro central da cidade. De acordo com dados disponíveis no sítio do Instituto Brasileiro de Geografia e Estatística (IBGE), referentes ao ano de 1900, Florianópolis possuía 32.229 pessoas; em 1920, este número subiu para 41.338; enquanto que em 1940, o total da população conformava 46.771 “almas”. Já em 1950, identificava-se, segundo registros censitários, a presença de 61.221 brancos, 5.027 pretos, 1.249 pardos, 03 amarelos e 130 sem declaração. ${ }^{1}$

Utilizar a documentação censitária desse período é bastante complicado, tendo em vista que, com o final do regime escravista e o processo de embranquecimento da população via imigração europeia, os Censos não mencionavam informações sobre a cor/raça. Os dados censitários de 1900 e 1920 não apresentam, em seus questionários, informações sobre a composição racial do Brasil. Apenas dados de sexo, idade e nacionalidade, fato que se altera em 1940, quando a composição racial (ou dados de cor) volta a aparecer nas estatísticas, além de informações sobre agricultura e indústria (RASCKE, 2018).

\footnotetext{
${ }^{1}$ Informação disponíveis na página eletrônica do IBGE:

<http://www.censo2010.ibge.gov.br/sinopse/index.php?dados=6\&uf=00 . Acesso em: 24 dez. 2016.
} 
No entanto, dentro da abordagem que nos interessa para esse texto, e a partir de reflexões proporcionadas por documentação existente sobre o período, em especial jornais, registros de atas de agremiações, estatutos de associações recreativas, cívicas e literárias ${ }^{2}$, compreendemos que percepções sobre cor/raça compunham dinâmicas distintas do funcionamento vigente no antigo sistema escravista, indicando a necessidade de dimensionar outras formas de situar classificações raciais presentes na sociedade daquele período.

Nem sempre os indicativos de cor/raça aparecem nos registros e, quando aparecem, constituem sinais mais sutis. Nesse sentido, alguns exemplos das décadas iniciais do século XX permitem melhor expressar, em que medida, tais sutilezas sugerem critérios de cor/raça no período. A União Recreativa 25 de Dezembro, associação fundada em 1933 no Morro do Chapecó, numa de suas atas, retomava que os brancos não poderiam dançar no salão. Em relação ao outro grupo, organizado em forma de agremiação, o Grêmio Recreativo e Carnavalesco Brinca Quem Pode, do qual localizamos um primeiro registro em jornal do ano de 1935, o indicativo recai sobre a terminologia de "morenos", sugerindo não se tratar de grupo branco. A mesma forma de expressar a cor foi utilizada pelo grupo do Tira a Mão, uma agremiação carnavalesca cujos registros encontrados situam-na no início da década de 1930, e que, em trecho de canção para o carnaval de 1935, acena para a composição racial de seus integrantes: "Morena/Moreninha/Do nosso bloco/Este ano és a rainha."3

Como essas agremiações, e as canções carnavalescas produzidas por muitas delas, lidavam com as marcas de origem africana deve ser pensado em termos de uma sociedade embebida nos ideais de mestiçagem e de democracia racial. Termos "fugidios", remetendo a vestígios ou marcas da escravidão, mas, que se pretende apagar, constituíam tensões do período, evidenciando os conflitos em torno de uma identidade nacional pautada em "elementos negros", menos o "próprio negro", pois sinais de associação a este eram considerados "escassa cultura” (CARDOSO; IANNI, 1960, p. 213).

\footnotetext{
2 O Literato (1914), A Urucubaca (1915), Folha Rósea (1915), XXIX de Maio (1920), Livros de poesia de Trajano Margarida, Obras de Ildefonso Juvenal e Antonieta de Barros, Registro do Estatuto da associação de homens de cor Centro Cívico e Recreativo José Boiteux (1921), Livros de Atas e Registros de irmãos da Irmandade Beneficente Nossa Senhora do Rosário e São Benedito, Atas da União Recreativa 25 de Dezembro e fotografias da época.

3 Jornal O Estado, 1 de março de 1935. Acervo da BPSC, setor de obras raras.
} 
Antonio Sérgio Alfredo Guimarães (2003, p. 247), observando noções de raça, cultura e identidade construídas em periódicos da imprensa negra de São Paulo e Rio de Janeiro, nas décadas de 1920 a 1950, discute estratégias variadas de mobilização de acordo com as socializações experimentadas por populações de origem africana na sociedade daquele período. Na perspectiva daqueles periódicos, a educação constituiria caminho para a igualdade, ou mecanismo cuja "cultura" indicaria possibilidade de “integração”. O autor enfatiza a perspectiva de grupos “letrados”, utilizando expressões orais e escritas como traçados para suas estratégias de lutas sociais e culturais.

Segundo Guimarães, "nos anos 1920 encontramos aqueles que são considerados pioneiros dos movimentos negros atuais", intelectuais que "chamam a si mesmos de ‘homens de cor' e 'homens pretos', e chamam seu coletivo de 'classe'. A princípio, as palavras "raça" e "negro" são usadas por eles de maneira bastante distinta da que hoje é usada pelos ativistas negros (GUIMARÃES, 2003, p. 250). Depreendemos que essas nomenclaturas, criadas pelos próprios grupos, como autodenominação, sugerem distanciamentos das amarras da escravidão e de suas memórias institucionais, no intuito de implodir ferramentas que as vinculassem à antiga condição de cativos. A noção de raça não obedece "qualquer realidade natural", como poderiam supor os teóricos racialistas do século XIX, denotando uma forma de classificação social, "baseada numa atitude negativa frente a certos grupos sociais, e informada por uma noção específica de natureza, como algo endodeterminado" (GUIMARÃES, 2009, p. 11). Nesse sentido, a raça é um construto social, mobilizado a partir da realidade de determinada sociedade e seus jogos de poder.

\section{Intelectuais e imprensa: O Literato, A Urucubaca, Folha Rósea e XXIX de Maio}

Alguns jornais e revistas foram publicados em Florianópolis nas décadas iniciais do século XX especificamente por redatores autointitulados homens de cor, sendo por estes liderados. O Literato, a Folha Rosea, a Urucubaca e o XXIX de Maio constituem foco de nossas abordagens, visando conhecer como, por meio desses veículos impressos, esses homens de cor expunham visões de mundo e concepções de sociedade. Ao refletir sobre a construção de um "novo negro na diáspora", no entendimento de Francisco (2016), os 
periódicos produzidos pela imprensa negra, tinham como propósito dialogar com esse público e "formá-lo", principalmente em "termos políticos", constituindo um “instrumento de interesse e intervenção na vida social” (FRANCISCO, 2016, p. 65).

A Abolição e a República trouxeram à tona debates em torno da cidadania e a quem ela se estendia. Afinal, dos considerados "cidadãos", poucos tinham acesso a bens materiais, escolas e direitos básicos. Diante disso, compete perceber que apenas alguns acessavam os bancos escolares, restringindo-se a $25 \%$ da população brasileiro o contato com as letras. Notícia publicada por grupo de estudantes do Curso de Comércio da capital catarinense em 1920, permite vislumbrar a situação da alfabetização no Brasil:

\begin{abstract}
$75 \%$ de analfabetos
O governo federal mandou publicar estatísticas a respeito da proporção de analfabetos que há em nosso país.

Em cada mil habitantes da Paraíba, apenas 168 sabem ler, sendo portanto, de 83,2 por cento a proporção de analfabetos. O segundo lugar cabe ao Piauí, com 173 que sabem ler para 827 analfabetos. Vêm depois (sempre em cada 1.000 habitantes) Pernambuco, com 807 analfabetos para 193; Alagoas com 800 analfabetos, Rio Grande do Norte, com 769; Ceará e Goiás com igual coeficiente de analfabetos 782; Bahia com 722; Rio de Janeiro (Estado) com 769; Paraná com 761; São Paulo e Sergipe com 753; Maranhão com 746; Minas Gerais com 744; Santa Catharina com 743; Espirito Santo com 731; Mato Grosso 730; Pará com 700; Amazonas com 678; Rio Grande do Sul com 674 e, finalmente, o Distrito Federal com 481 analfabetos contra 519 que sabem ler ${ }^{4}$.
\end{abstract}

Essa estatística de 1920 indica que o país não tinha uma população escolarizada. Apenas $25 \%$ dos residentes no Brasil tinham contato com a escrita e a leitura, as chamadas primeiras letras. Considerando que muitos desses eram vinculados à política, às elites dirigentes, ou eram as próprias elites financeiras, têm-se uma realidade que faz crer no pequeno percentual de homens e mulheres empobrecidos com acesso à escolarização, "recorte" em que se assenta o número também muito reduzido de homens e mulheres de origem africana escolarizados ou, que por meio de espaços "alternativos", alheios ao sistema oficial de ensino ${ }^{5}$, tiveram acesso ao mundo letrado.

\footnotetext{
4 Jornal CPC - Órgão Mensal dos Estudante dos Curso Prático de Comércio, Florianópolis, 15 de outubro de 1920, ano 1, Número 5.

${ }^{5}$ Irmandades religiosas, escolas noturnas fundadas por sociedades recreativas, grupos teatrais e tantos outros meios de alfabetização e oferta de cursos profissionalizantes foram constituídos como forma de possibilitar acesso à educação às camadas "esquecidas” pelos governos.
} 
Desses dados, que para o governo eram alarmantes, podemos depreender alguns apontamentos e também questões. O primeiro deles é que no Brasil havia uma realidade multilinguística, formada por povos indígenas, populações de origem africana e também imigrantes europeus de diferentes nacionalidades, indicando pluralidade em termos de línguas, culturas e formas de compreender o mundo. Assim, é possível que inúmeras pessoas tivessem conhecimento letrado, ou seja, fossem alfabetizadas, mas não em idioma nacional.

Outro ponto remete aos $75 \%$ da população residente no Brasil considerada analfabeta, sugerindo que a transmissão de conhecimento se dava por outros meios que não a escrita. Uma "série de linguagens corporais e expressões de memória poderiam ser ativadas para transmitir o que a escrita não fazia, visto que não era utilizada por uma grande parcela da população, ou, pelo menos em idioma dito nacional” (RASCKE, 2018, p. 135). Ao mesmo tempo, o restrito acesso ao universo letrado permite supor que as relações de poder se faziam pautadas também no controle sobre quem escrevia, o que escrevia e para quem.

Em termos de acesso à leitura e formação de periódicos da imprensa negra, dimensionar como essa produção chegava aos membros integrantes de associações ou a comunidade em geral, envolve refletir sobre as ferramentas utilizadas para divulgação desse tipo de material, desde a mobilização para compra dos exemplares como meio de financiamento, até a transmissão oral de matérias e ideias constantes nas páginas dessas folhas àqueles que não dispunham de conhecimento letrado.

Regina Pahim Pinto (2013) discutiu os movimentos negros em São Paulo, a construção identitária e de luta, desde as primeiras décadas do século XX. Em seu entendimento, os jornais da imprensa negra, uma "elite negra letrada", consideravam o analfabetismo um empecilho, "a causa de vários males que afetam o negro: a apatia, a falta de ideal e de objetivos" (PINTO, 2013, p. 213). Na visão desses intelectuais, atuantes em sociedades recreativas e jornais, a instrução seria uma forma de superação da situação de precariedade social vivenciada pelas populações de origem africana. 
Cardoso (2012, p. 59), a respeito de sociedades recreativas e imprensa negra em São Paulo nas primeiras décadas do século XX, aponta que uma das características dessas diferentes associações implicava mobilizar "esforços na promoção de eventos lúdicos, como quermesses, ensaios e saraus dançantes". Seu estudo, dissertação de mestrado produzida na década de 1990, trouxe à tona lutas e embates da imprensa negra de São Paulo nas décadas de 1915 a 1930, assinalando que outros grupos, de "não-letrados", produziam estéticas e visões de mundo para além do universo letrado ou dos anseios de grupos de letrados.

\section{O Literato: órgão do Centro Literário Castro Alves}

Adentrando na análise dos quatro periódicos indicados para a reflexão proposta neste artigo, as próximas linhas examinam O Literato, produção de um grupo literário vinculado ao Centro Literário e Recreativo Castro Alves, fundado em 1914, tendo entre seus integrantes João Melchíades de Souza, Trajano Margarida e Nicolau Nagib Nahas. Apenas um exemplar do periódico encontra-se disponível no acervo da Biblioteca Pública do Estado de Santa Catarina, datado de 6 de dezembro de 1914, registrado como número 1 do que se pretendia ser um veículo quinzenal de divulgação das produções e ideias do Centro. Com sede provisória à Rua Tiradentes, na residência de Nahas, o Centro recebia inúmeras doações para sua biblioteca e havia registrado um estatuto, documento não localizado em acervo até o momento.

Os três organizadores do Centro e de O Literário compunham o grupo de literatos locais, desenvolvendo atividades e parcerias para divulgação da produção literária daquele período. Nahas era poeta e teatrólogo, filho de migrantes libaneses que residiam em Campos dos Goitacazes (Rio de Janeiro) e migraram para Florianópolis; Melchíades de Souza, também poeta, vinha de família com envolvimento na política e na polícia militar; enquanto Trajano Margarida (1889-1946) era "amanuense da Secretaria do Interior do Estado de Santa Catarina, professor, jornalista, educador, autor de diversas obras literárias e membro fundador de entidades cívicas e literárias" (GARCIA, 2011, p. 1).

Margarida, conhecido como “o poeta do povo" (THIAGO, 1957, p. 391), homem de origem africana, apresentou em suas narrativas uma Florianópolis pautada em 
personagens pobres, benzedeiras, prostitutas, órfãos, mendigos... as marcas de uma modernização e de uma Abolição não tão bem encaminhadas, "gente que revela a cidade desajustada, incômoda e inconveniente diante dos anseios e projetos pensados pelas elites" (PEREIRA, 2001, p. 14). Participou da fundação e da gestão de diferentes jornais, associações, centros, clubes e sociedades ${ }^{6}$, dentre eles o Centro Literário e Recreativo Castro Alves (1914); uma associação exclusiva de homens de cor chamada Centro Cívico e Recreativo José Boiteux (1921), de onde era presidente; o Figueirense Futebol Clube (1921), onde atuava como orador e clube a que dedicou uma canção às vésperas do Natal daquele mesmo ano; o Centro Catarinense de Letras (1925); inúmeros jornais e periódicos, além de livros de sua própria autoria?

Figura atuante e conhecida na capital catarinense, Margarida escrevia textos e versos para jornais, semanários e revistas, destacando percepções políticas, sociais, estéticas e econômicas da cidade nas primeiras décadas do século XX. A história de vida de Trajano Margarida consistiu em muitas batalhas, desde o seu nascimento em família pobre "de cor". "Vive, porém, no meio da multidão, sofre com ela, sorri, desdenha e glorifica junto com ela" (CALLADO, 1945, s/p). De “casebre em casebre”, oferecendo "versos modestos ao som dos violões", "cantando nos picadeiros", Trajano Margarida tirava seu sustento da poesia, musicando seus versos embebidos em alegrias, tristezas, amores, sofrimentos com a perda e o racismo.

\footnotetext{
6 “Inúmeras agremiações existentes em Florianópolis na primeira metade do século XX constituíam territórios negros na cidade, áreas e formações reorganizadas nas reformas urbanas e ressignificadas por seus pertencentes. Algumas figuras ativas em Florianópolis marcaram também a construção de uma visibilidade positiva almejada por muitos homens e mulheres agremiados, como Antonieta de Barros e Leonor de Barros, Trajano Margarida, Ildefonso Juvenal da Silva e Demerval Cordeiro; atuaram política e educacionalmente para criar possibilidades de ascensão social de afrodescendentes nas primeiras décadas da República. Articulados em jornais, espaços políticos, constituindo escolas e ministrando curso primário, propunham a educação como forma de ascensão social e melhores condições de vida. Oportunamente, cabe mencionar que esses personagens, diante dos empecilhos impostos pela Academia Catarinense de Letras à participação de mulheres e de descendentes de africanos, fundaram seu próprio Centro, o Centro Catarinense de Letras em 1925. Articulando saberes letrados e vivências embebidas em memórias africanas, trata-se de homens e mulheres imersos em lutas que consideravam importantes e necessárias no período. As décadas de 1910 até 1930 marcaram o surgimento da Associação de Homens de Cor, do Centro Catarinense de Letras e dos Clubes Recreativos de origem africana, sugerindo atenção para os cuidados com a escolarização, a educação formal de afrodescendentes" (RASCKE, 2017, p. 355).

7 A respeito dessas associações e seus integrantes, sugerimos as seguintes bibliografias: GARCIA, 2011; PEREIRA, 2001.
} 
O poeta, marcado por memórias e vivências da avó, ex-escravizada, carregava em suas letras e canções, saberes de tradições orais afro, articulando, por meio de escritas carnavalescas, canções e versos, "arquivo e repertório", como salienta Diana Taylor (2013), consistindo em assentamento considerado arquivo por seu papel arquival, ao passo em que o repertório consiste em sistema não arquival de registro da performance, "um sistema de aprendizagem, armazenamento e transmissão de conhecimento" (TAYLOR, 2013, p. 45), que se reatualiza a cada encenação ou performance, refazendo-se.

A imprensa negra produziu registros arquivais, por seu papel e suporte, diferentemente de outras práticas sintonizadas a repertórios - "efêmeros, de práticas/conhecimentos incorporados" (TAYLOR, 2013, p. 45), constituídas em distintas formas de organização de associações festivas, religiosas, esportivas e carnavalescas, que encenavam a memória incorporada, por meio de performances, gestos, movimentos, danças e cantos, conhecimentos não reproduzíveis, não arquiváveis, tornados únicos, reatualizados a cada nova encenação/rememoração. Entretanto, o registro arquival dessa produção de imprensa possibilita captar estratégias de letrados de origens africanas frente a sistemas de racismo e discriminação, suscitando compreendermos modos distintos de lidar com a memória, com os universos culturais e o combate ao racismo a partir de estéticas diversas.

Retomando a produção de O Literato, com base no que constaria no estatuto do Centro Literário e Recreativo Castro Alves ${ }^{8}$, o periódico indica uma tensão entre diferentes grupos literatos da cidade, apontando "a necessidade de defender-se dos ataques injustos daqueles que a todo transe querem derrotar o ardente amor que seus associados consagram a literatura" ${ }^{9}$. Essa narrativa faz-se constante em outros periódicos e abordagens de intelectuais negros daquele período, sinalizando conflitos raciais marcados por embates envolvendo espaço, visibilidade, educação e alguma expectativa de ascensão social.

\footnotetext{
${ }^{8}$ O Centro Literário e Recreativo Castro Alves, bem como o Centro Catarinense de Letras, também mencionado nesse texto, não eram associações exclusivas organizadas por afrodescendentes, mas, articulavam diferentes intelectuais, homens e mulheres, afros e brancos, no sentido de construir caminhos alternativos às regras impostas pelos chamados "beletristas" da época e suas produções.

${ }^{9}$ O Literato - Orgam do Centro Literário e Recreativo Castro Alves. Florianópolis, 6 de dezembro de 1914, n. 1. Setor de Obras Raras da Biblioteca Pública do Estado de Santa Catarina. Disponível em: <http://hemeroteca.ciasc.sc.gov.br/jornais>.
} 


\section{A Folha Rosea e a Urucubaca}

Dois periódicos produzidos em Florianópolis, sob redação de Ildefonso Juvenal, constituem foco de análise com maior abrangência, dada a ênfase dessas folhas nos conflitos raciais daquele momento. Uma revista, intitulada Folha Rosea, lançada em 1915, e um jornal com número único, o XXIX de Maio, posto à venda em 1920, constituíam produções valorizando a leitura, a instrução e a República.

Ildefonso Juvenal, nascido em 1894, também em Florianópolis, foi aprendiz de tipógrafo na Marinha, chamada Escola de Aprendizes de Marinheiros, sendo que com 20 anos de idade já escrevia poemas bastante elogiados pelo público leitor e por intelectuais da época, muitos ingressantes da Força Pública. Em 1918, integrava os quadros da Força Pública, desenvolvendo ação também como alfabetizador de praças. Participou de inúmeras associações, fundou jornais e revistas, escreveu em diferentes periódicos, publicou livros e foi farmacêutico da Força Pública - em 1921 tinha iniciado o curso de Farmácia no antigo Instituto Politécnico ${ }^{10}-$, além de fundador e atuante no bloco carnavalesco Tira a Mão - vinculado à Força Pública. Envolveu-se ativamente na vida pública da cidade, dialogando com numerosos políticos e, em especial, demonstrava afeto e respeito por Hercílio Luz, com quem mantinha relações. Importante mencionar também sua atuação nas Academias de Letras de outros estados ${ }^{11}$, no Instituto Histórico e Geográfico de Santa Catarina, bem como na Comissão de Folclore do estado (GARCIA, 2007; SILVEIRA, 2015).

Flavio Thales Ribeiro Francisco (2016), em estudo sobre o periódico Chicago Defender (1916-1940) - folha da imprensa negra - nos Estados Unidos, argumenta que a

\footnotetext{
10 "Primeira instituição de ensino superior do Estado de Santa Catarina, o Instituto Politécnico foi criado no ano de 1917. Em 14 de fevereiro daquele ano, os jornais O Estado e A Época, de Florianópolis, noticiaram a respeito de sua fundação que se efetivou com uma reunião de cirurgiões-dentistas, farmacêuticos e médicos, além de engenheiros, bacharéis em direito, um oficial da Marinha e um guarda-livros, que decidiram pela formação de comissões para elaboração dos planos de cursos que integrariam a instituição - odontologia, farmácia, comércio, agrimensura e pilotagem." INSTITUTO POLITÉCNICO DE FLORIANÓPOLIS. Disponível em: http://www.dichistoriasaude.coc.fiocruz.br/iah/pt/pdf/instpolytflo.pdf. Acesso em: 27 dez. 2017. Atualmente, a sede do antigo Instituto divide-se entre o Instituto Histórico e Geográfico de Santa Catarina e a Academia Catarinense de Letras.

${ }^{11}$ Em 1945, por exemplo, era sócio correspondente da Academia Sul-Rio Grandense de Letras. "Em ofício dirigido ao nosso colaborador sr. Tem. Farm. Ildefonso Juvenal, comunicando-lhe aquela acertada resolução dos intelectuais gaúchos e lhe confirmando como um dos embaixadores das letras sulriograndenses em nosso Estado [...]." A Gazeta, Florianópolis, 3 de fevereiro de 1945.
} 
posição política normalmente explicitada era em favor do Partido Republicano, "nunca esquecendo o papel deste na abolição da escravidão, reforçando sua aura associada ao presidente Abraham Lincoln" (FRANCISCO, 2016, p. 43). No caso brasileiro, evidencia-se que a menção aos abolicionistas, muitos deles vinculados ao Partido Republicano, também se fez notar de forma bastante enfática.

A Folha Rosea, surgida em 15 de novembro de 1915, lançada no dia da Proclamação da República no Brasil, dirigida pelo intelectual Ildefonso Juvenal, assim comunicou-se com seu público leitor na primeira publicação:

\section{A NOSSA MIRA}

Surge hoje entre risos e festas, a modesta revista "Folha Rosea".

- O que pretendemos fazer? Perguntarão todos, cheios de curiosidade.

- O que pretendemos fazer, respondemos pressurosos: é unicamente pugnar pelos interesses dos "Novos"; facilitando-lhes meios de desenvolver as suas ideias.

Sim, porque até então, eles têm sido uns mártires.

Ora o grupo dos "beletristas" a tirar-Ihes o mérito; ora parte da Imprensa a ridicularizar as suas produções.

Enquanto a mocidade paranaense associa-se, para unidos desenvolverem a literatura no seu Estado, a nossa mocidade, desunida, uma parte deixase ficar imóvel, outra: vive quer nos cafés, quer no jardim, nos bondes, a ridicularizar as produções literárias dos principiantes.

O saber, é privilégio de meia dúzia de rapazes, que, nasceram sábios, tornaram-se imortais, e hão de voar amanhã em aeroplanos às regiões Parnasianas...

Mas os "Novos" erguem-se hoje, e a "Folha Rosea", há de demonstrar que os pequenos podem ainda ser grandes.

Por motivos imperiosos, suspendeu a publicação o intemerato jornal “A Urucubaca"”2.

No pequeno diálogo bastante criativo com o leitor, a revista diz ter surgido entre “risos e festas", consagrando ser disposição daquele folhetim pugnar pelo interesse dos "Novos", que o redator usa entre aspas, por ironia, criticando de forma indireta a Sociedade Catarinense de Letras (depois Academia Catarinense de Letras), visto as batalhas em torno do poderio cultural e intelectual que se propunha verdadeiro, civilizado e esteticamente adequado.

\footnotetext{
${ }^{12}$ Revista Folha Rosea, Florianópolis, 15 de novembro de 1915, ano I, número 1. Acervo da Hemeroteca Digital da Biblioteca Pública do Estado de Santa Catarina. Disponível em: <http://hemeroteca.ciasc.sc.gov.br/jornais/Folha\%20Rosea/FOL1951001.pdf 〉. Acesso em: 15 abr. 2016.
} 
Essa expressão, "novos", remetia àqueles que, constantemente, necessitavam defender-se de críticas diversas por conta de sua opção pela literatura, além do fato de que os "famosos beletristas" da época acreditavam ser os únicos dotados do poder das letras, autointitulados capazes de iluminar a cidade com suas poesias e prosas. Ildefonso Juvenal enfoca que os chamados "Novos" eram praticamente mártires, tamanho sofrimento e críticas oriundas de todas as partes, ora dos "beletristas", ora da imprensa, que também por estes, em grande parte, era formada. Ao utilizar a expressão de que a imprensa ridicularizava essas produções, tem-se dimensão de embates e dissabores corriqueiros naquela sociedade das letras, mas, principalmente, porque o domínio das letras deveria ser apenas para alguns.

O redator reforça, em sua crítica aos "beletristas", que o saber "é privilégio de meia dúzia de rapazes, que, nasceram sábios, tornaram-se imortais, e hão de voar amanhã em aeroplanos às regiões Parnasianas..."13. Interessante notar o acentuado tom nevrálgico com relação ao saber. Na visão de muitos "eruditos" da época, nem todos alcançariam o requinte das belas letras, do formato perfeito das poesias cultas parnasianas. Por isso a tônica de Ildefonso Juvenal sobre os intitulados "beletristas", donos das boas letras e formas perfeitas, dignas da língua culta, em contraposição, pensavam eles, aos ditos "poetas menores", cujas formas poéticas e estéticas das crônicas tinham cadências e construções narrativas próprias.

Vivências de matrizes culturais orais se internalizavam ou externalizavam de diferentes modos, dentre eles, a própria produção textual articulada por letrados de origem africana, contendo formas e encaminhamentos outros, distintos de formatações do universo branco letrado e/ou de "beletristas". Nesse sentido, além dos impasses envolvendo a cor dos produtores de determinada literatura, a própria existência dessa produção e suas formas de expressão sugerem tensões raciais constantes, camufladas, muitas vezes, sob a denominação de "inabilidade" para as letras.

Ainda, em relação à matéria sobre a chegada da Folha Rósea ao público, o redator insere uma nota explicando que por motivos "imperiosos" não explicados, o jornal $A$ Urucubaca deixava de ser produzido. Caracteriza-o como "intemerato”, um periódico que

\footnotetext{
${ }^{13}$ Ibidem.
} 
Estado de Santa Catarina ${ }^{14}$, fazendo crer que, ou apenas aquele número foi possível, ou os demais números acabaram consumidos pelas marcas do tempo e do pouco cuidado com registros dessa natureza.

Por que motivo Juvenal deixava aquele projeto de lado? Quais eram as prioridades no momento para que chegasse ao ponto de optar por um periódico e desvencilhar-se do outro? Questões para as quais ainda não temos respostas, mas podemos pensar que, tratando-se de publicações de uma imprensa efêmera, nem sempre com muitos recursos para financiamento, talvez procurasse concentrar suas ações, ideias e produções em um periódico específico, mais apropriado aos objetivos daquele intelectual naquela ocasião.

Na mesma edição de lançamento da folha, Ildefonso tece uma narrativa sobre a importância do livro, cujas "paginas é onde o jovem esperançoso busca o seu enobrecimento", instrumento que tornaria os jovens "dotados de uma inteligência cultivada, capaz de dirigirem-se a si mesmos, desenvolvendo sua atividade e sua arte, nunca chegando ao desgosto que hoje os mortifica"15. O intento do intelectual era despertar nos jovens o interesse pela leitura, ao passo que esta também seria uma possibilidade de desenvolvimento, logo, de algum tipo de ascensão social. Meios de usar as mesmas ferramentas dos brancos letrados.

Oportunamente, Juvenal dialoga com os operários, "honestos e bondosos" que, apesar "de cansados pelo labor diurno, e, que seguiam o mesmo caminho, já vão à noite ao Liceu, mesmo ao rigor do tempo, esperançosos de pelas tuas páginas irem instruindose, porque a instrução é uma das cousas mais úteis ao homem" "16. Tratava-se de um estímulo aos operários, que labutavam em suas lides diárias em trabalhos árduos, mas procuravam estudos como forma de alcançar novos argumentos e, talvez, as possibilidades e visibilidades trazidas por estes códigos de comunicação, linguagem e poder.

\footnotetext{
${ }^{14}$ A Urucubaca - Jornal Crítico e Humorístico. Florianópolis, 22 de agosto de 1915, n. 1.

${ }^{15}$ Ibidem.

${ }^{16}$ Ibidem.
} 
A Folha Rosea também era espaço de divulgação de ações, publicações e obras de intelectuais de origem africana na cidade. Neste sentido, uma matéria publicada no dia do Natal de 1915, sobre o livreto de Trajano Margarida, lançado um ano antes, intitulado "Natal do Orfãozinho", visava elogiar os esforços de Margarida naquela produção e também seu ímpeto na realização de outra publicação em fase de preparação, comentando ao público leitor que "não faltaram espíritos maléficos, que pretendessem desprestigia-lo"17. Ironizava que estes "beletristas e críticos" precisavam de "chineladas", visto não as terem recebido durante a formação na infância. Finaliza a narrativa apoiando “Trajano que foi também como nós um mártir dos 'sabichões' insensatos”"18.

O periódico era uma publicação quinzenal chefiada por Ildefonso Juvenal, compondo seu grupo editorial os seguintes nomes: Diretor - Ildefonso Juvenal; Secretário - João Melchiades; Colaboradores: Amphiloquio Pires, Trajano Margarida, Almeida Coelho, Nicolau Naib Nahas, Crispim de Freitas Junior, Nelson Gama, Celso Coelho, João Paiva, Agricola Guimarães, Geraldino Azevedo e Antonio Peixoto. Esses homens, muitos deles identificados com a noção de homens de cor e participantes do Centro Cívico e Recreativo José Boiteux - uma associação de homens de cor -, também colaboraram em outras propostas coletivas, pautando a educação, a escolarização e a importância das letras como mecanismo de transformação e ascensão social.

Neste sentido, foram homens de letras participantes de associações, centros literários, cursos de alfabetização de crianças e também adultos, agremiações esportivas, recreativas e lúdicas, também deixando em impresso, registrado nos veículos da imprensa, seus pensamentos e propostas para a capital, no estado de Santa Catarina e o futuro do país, a partir de seus universos culturais e posicionamentos políticos.

Um grupo de intelectuais de origem africana, naqueles idos de 1915, organizou mobilização e evento para compartilhar "seus sonhos e esperanças", além de "vislumbrar o levantamento social, cultural, intelectual e moral dos homens negros" (DOMINGUES, 2011, p. 119). Em comemoração à Abolição, Ildefonso Juvenal e Trajano Margarida atraíram um grupo de homens de cor e organizaram uma solenidade no Teatro Álvaro de

\footnotetext{
${ }^{17}$ Revista Folha Rosea, Florianópolis, 25 de dezembro de 1915, ano I, número 3.

${ }^{18}$ Ibidem.
} 
Carvalho, "reunindo negros e brancos, homens e mulheres, autoridades públicas, representantes da imprensa e de outras associações da sociedade civil de Florianópolis" (DOMINGUES, 2011, p. 120), homenageando Cruz e Souza e retomando sua memória como símbolo para perspectivas intelectuais de homens de cor. Ildefonso Juvenal, então com 21 anos, e Trajano Margarida, com 26, eram os idealizadores, aliados a Astrogildo Campos.

Paul Connerton (1999, p. 15) compreende que "o conhecimento de todas as atividades humanas passadas só é possível através do conhecimento dos seus vestígios [...] - isto é, as marcas, perceptíveis pelos sentidos, deixadas por um fenômeno qualquer em si inacessível”. Tais vestígios, marcas de presença e atuação humana, proporcionam alcançar elementos constituintes das organizações sociais humanas, viabilizando interpretações dessas sociedades sobre/de si mesmas e análises históricas relacionadas as suas perspectivas e modos de ser e estar no mundo.

A memória de Cruz e Souza, cuja morte ainda se fazia presente, possibilitava a intelectuais autointitulados homens de cor, preservar e recriar imagens positivas de si mesmos e de seus objetivos enquanto literatos. Resistências, renovações culturais, reatualizações memoriais, registradas em papel - tingido pela caneta -, apesar de produto cultural ocidental, permitia constituir "expectativas baseadas na recordação" (CONNERTON, 1999, p. 7). Neste caso, recordar o poeta suscitava rememorar sua obra, sua vida e a perspectiva de visibilidade pela poesia, pela arte da escrita.

O encontro cívico, em homenagem ao 13 de maio, aconteceu um ano antes, em 1914, primeiro registro que localizamos, e depois, em 1915, com divulgação melhor detalhada em jornal, além de informações sobre quem seriam estes homens de cor, idealizadores do momento festivo. Os dois literatos, apesar de jovens, possuíam articulações políticas na capital catarinense, tendo realizado o evento em anos consecutivos, contando com familiares, visitantes e autoridades políticas da época ${ }^{19}$.

Segundo notícia: “A comissão organizadora da festa foi incansável em seus trabalhos para que a mesma seja coroada de grande êxito. Fazem parte da comissão os

\footnotetext{
19 Jornal O Estado, 13 de maio de 1915, número 1. Disponível no acervo da BPSC, setor de obras raras.
} 
de homens e mulheres de cor na capital catarinense.

O evento de 1915 contou com discursos dos organizadores, momentos de declamações e hinos, além de discursos e homenagens de autoridades e para autoridades, na comemoração. Quais esforços e estratégias teriam utilizado para mobilizar o público a comparecer ao evento? Por que o homenageado principal teria sido o Coronel Wendhausen, para além do fato de ser um abolicionista conhecido? Além disso, aquele era o segundo ano em que o referido nome aparecia entre as autoridades homenageadas.

\section{XXIX de Maio: número único}

Outro material que analisamos nestas páginas constitui situação também peculiar, pois o próprio folhetim afirmava ser número único, sendo produzido em benefício da Escola Noturna Cruz e Souza. Com o nome XXIX de Maio, lançado em 29 de maio de 1920, data de aniversário do então governador Hercílio Luz, o jornal era uma homenagem do Centro Cívico e Recreativo José Boiteux ao governador, ressaltado pela folha como “eminente chefe de nossa democracia, ao grande dirigente de nossos destinos, toda a admiração e respeito e o felicitamos afetuosamente por mais esse marco plantado na estrada utilíssima de sua preciosa existência”21.

Ao que tudo indica, fazia-se muito importante para este agrupamento de homens de cor a consolidação do projeto da herma, posto em evidência no estatuto do Centro Cívico e Recreativo José Boiteux, elaborado em janeiro e registrado em 14 de julho de 1920. No período em que toda essa movimentação em prol da herma em memória de Cruz e Souza estava em pauta, o Estatuto destacava tratar-se de "uma associação esclarecidamente de homens de cor", criada com o intuito de "levantar em uma das

\footnotetext{
${ }^{20}$ Ibidem.

${ }^{21}$ Jornal XXIX de Maio, Florianópolis, 29 de maio de 1920, número único. Em benefício da escola noturna Cruz e Souza. Organizada por ILDEFONSO JUVENAL (caixa alta no original).
} 
praças públicas de Florianópolis, a herma do saudoso e imortal poeta Cruz e Souza", além de "proporcionar aos seus associados a instrução cívica e literária e recrear os mesmos e suas respectivas famílias" 22 .

Conforme depreendemos do objetivo principal dessa associação, a homenagem ao poeta Cruz e Souza constituía tarefa importante e, consequentemente, o grupo não envidou esforços para alcançar essa meta, efetivada em 07 de abril de 1923. Quando da inauguração, a herma para Cruz e Souza estava na Praça Benjamin Constant, achando-se atualmente alocada na Praça XV de Novembro, no centro histórico de Florianópolis.

Interessante que quase todo o número discute a personagem política de Hercílio Luz, além de reservar espaço também para o patrono do Centro, José Arthur Boiteux, naquele ano Secretário do Interior e Justiça. A este último, Ildefonso faz uma nota com palavras dedicadas de gratidão. Quanto a Hercílio Luz, o redator daquela folha constrói uma narrativa extensa enfatizando ser hercilista e explicando os motivos de sua opção política.

Começa o texto informando que, em sua concepção, a infância ainda não constitui período da vida capaz de situar-nos politicamente, mas ressalta que aquele "tempo feliz em que a nossa ingenuidade não nos deixa sequer uma vaga compreensão sobre o artificioso engenho que é a Política, já eu tinha pelo grande estadista que é Hercilio Luz uma grande afeição" 23 . Sua argumentação ressalta qualidades do estadista, "a admirar com a luz clara da razão, o seu caráter impoluto, a nobreza de seus sentimentos cristãos, o seu espirito clarividente". A sequência esboçada por Ildefonso aponta para as dificuldades de sua vida e sua entrada na Força Pública, tarefa não menos complexa e difícil.

E não foi debalde que eu senti essa grata sensação de alegria. Na minha terra eu tinha sido, até então, um mendigo, um infeliz abandonado. Acossado pela necessidade, eu, reconhecendo embora que a farda do soldado não é desonra, mas que não nasci para ser um soldado profissional, e unicamente para enverga-la na hora precisa, em que a

\footnotetext{
${ }^{22}$ Estatuto do Centro Cívico e Recreativo José Boiteux, Florianópolis, 14 de julho de 1920. Acervo do Cartório Iole Faria, atualmente denominado Cartório Florianópolis, folhas 20-22; Jornal República. Florianópolis, 03 mar. 1921, n. 717, p. 03. Acervo da BPSC, setor de obras raras.

${ }^{23}$ Ibidem.
} 
Pátria apele para o meu civismo de brasileiro, fui obrigado a fazer da farda de soldado de polícia uma profissão, para poder manter a minha família! Nunca ninguém me deu a mão. Todo mundo sabe que eu não sou um analfabeto; que leio já sem soletrar a Cartilha Analítica e sei rabiscar o meu nome, entretanto a todos os governos eu esmolei e nenhum deles quis admitir-me em uma repartição, nem sequer como simples auxiliar de escrita!

Era que ainda não tinha subido a curul governamental um homem que soubesse por de lado todas essas coisinhas pequeninas e supérfluas, como o é o exclusivismo de cor, e julgar o indivíduo pelas suas qualidades morais e intelectuais, como compete ao homem criterioso e honesto.

Hercilio luz foi o primeiro que deu aos seus conterrâneos esse exemplo salutar.

Foi ele que reconhecendo o meu modesto e embora insignificante préstimo para coisas mais elevadas, tirou-me das mãos o espadagão policial e deu-me uma pena, que é o símbolo da Inteligência, como um mudo estímulo o Estudo para a Perfeição.

É por isso que eu sou Hercilista, e sê-lo-ei até a Morte porque a Gratidão me ordena ${ }^{24}$.

O trecho traz detalhes da vida de lutas do intelectual afrodescendente por um espaço onde pudesse exercer um trabalho adequado aos seus conhecimentos e ao seu ideário, o que, segundo ele, em governos anteriores não era visto, pois esses governantes e suas políticas não percebiam as demandas de uma camada considerável da população catarinense, ávida por vivenciar o que a cidadania, após a Abolição, poderia significar e proporcionar. Frustrado com as negativas que sempre recebia, Ildefonso foi "obrigado a fazer da farda de soldado de polícia uma profissão, para poder manter a minha família! Nunca ninguém me deu a mão" 25 .

A labuta para sobreviver e tentar tornar a vida dos seus mais acessível e menos difícil financeiramente o fez entrar na polícia, uma área e um recurso utilizado por muitos homens afrodescendentes naquele período. Tratava-se da possibilidade de conseguir um emprego fixo e remunerado com regularidade. No entanto, esse não era o sonho de Ildefonso Juvenal, tampouco considerava estar apto a apenas aquilo. Pretendia mais, almejava mais, "entretanto a todos os governos eu esmolei e nenhum deles quis admitirme em uma repartição, nem sequer como simples auxiliar de escrita!”.

\footnotetext{
${ }^{24}$ Ibidem.

${ }^{25}$ Ibidem.
} 
Diferentemente, durante a gestão de Hercílio Luz, na visão de Ildefonso Juvenal, a situação havia se transformado, pelo menos no entendimento de alguns homens de letras. Como o redator salienta, Hercílio não julgaria pela cor, mas pelas capacidades morais e intelectuais dos seus contratados e apoiados, o que teria permitido a esses homens, em especial, uma oportunidade, uma possibilidade de galgar espaços e expressar em diferentes meios, inclusive e, principalmente, na imprensa, os seus pontos de vista e suas percepções poéticas, éticas e estéticas daquela capital catarinense.

Em nossa compreensão, o número único publicado pelo intelectual Ildefonso Juvenal articulou de modo estratégico uma homenagem a Hercílio Luz - o que deve ter rendido bons recursos na venda daquele jornal -, ao mesmo tempo em que expressou de modo sintomático a preocupação com a alfabetização de crianças e adultos, numa sociedade excludente e acomodada com a situação de ex-escravizados, então livres, mas traídos por um sistema que os invisibilizava e impedia de ascenderem socialmente.

Em terras catarinenses, o 13 de maio continuou sendo, alguns anos após mobilizações iniciais daquele grupo de homens de cor, momento de comemoração e homenagens aos abolicionistas e renomados homens e mulheres de origem africana nascidos na capital catarinense, envolvidos com as lutas diárias contra as marcas e os estigmas da escravidão. Assim, naquele 13 de maio de 1920, o Centro Cívico e Recreativo José Boiteux realizou uma solenidade, "inaugurando em seu salão o retrato do insigne e saudoso poeta Cruz e Souza e a distribuição de diplomas aos seus associados [...] no espaçoso palacete da Praça 17 de novembro" ${ }^{26}$.

O evento teve início às 19 horas e contou com autoridades, dentre elas o Governador do Estado de Santa Catarina, Coronel Raulino Horn ${ }^{27}$ e José Boiteux, Secretário do Interior e Justiça e interino da Fazenda. A música ficou a cargo da banda da Força Pública. Na ocasião, André José Pinheiro era o Presidente do Centro, também

\footnotetext{
${ }^{26}$ Jornal A Republica, Florianópolis, 15 de maio de 1920, ano XV, número 479. Acervo da Hemeroteca Digital da Biblioteca Nacional. Disponível em: <http://memoria.bn.br/DocReader/DocReader.aspx ?bib=711497x\&PagFis=15124\&Pesq=>. Acesso em: 15 nov. 2016. A referida Praça 17 de novembro situa-se na região central de Florianópolis, área que no começo do século XX denominava-se bairro Mato Grosso. Hoje, essa praça é conhecida popularmente como "Praça dos Bombeiros", mas sua nomenclatura registrada é Praça Getúlio Vargas.

27 O Governador do estado entre 1918 e 1922 era Hercílio Luz, mas o coronel Raulino Horn, enquanto presidente da Assembleia Legislativa, assumiu várias vezes a função de governador em exercício, durantes viagens e outras demandas do governador Hercílio Luz.
} 
associado à Irmandade Beneficente de Nossa Senhora do Rosário e São Benedito, onde seu primeiro registro data de 1885, ainda em tempos de escravidão vigente, mas aparece identificado como livre ${ }^{28}$. João Ubaldo Falcão, então $1^{\circ}$ secretário do Centro Cívico, "fez a leitura da ata da sessão anterior, terminada a qual começou a fazer a chamada dos associados para recepção dos diplomas que por um requinte de gentileza eram entregues pelo exmo. coronel Governador e recebidos com imensa satisfação"29. A "gentileza", provavelmente, continha afirmação e expunha seu poder.

Finda a distribuição dos diplomas aos associados, Falcão passou a palavra a Ildefonso Juvenal, orador da associação. O discurso, infelizmente, não fez menção expressa ao retrato de Cruz e Souza e à importância daquela solenidade em homenagem ao poeta, há menos de três décadas falecido vítima de tuberculose e do descaso da sociedade racista de então. Naquela ocasião, pautou bem mais o apoio político a Hercílio Luz: "Sede bem-vindo aquele que na grande luta em prol do levantamento moral e material de sua terra, foi e será sempre um triunfador e um herói" ${ }^{30}$.

Antes do discurso de Ildefonso Juvenal, a solenidade contou com a inauguração do retrato do poeta Cruz e Souza, "cujo riquíssimo quadro foi descerrado por uma gentil menina. Ao aparecer a imagem do grande poeta, a assistência levantou-se saudando com uma prolongada salva de palmas"31. Ainda, na sequência daquele ato, se pronunciaram: Bittencourt Machado, Trajano Margarida (Vice-Presidente do Centro), a menina Maria

${ }^{28}$ Outras duas matrículas também foram registradas em seu nome, uma ainda em 1885, com duração até 1915 e outra de 1917 a 1925. Depreendemos que esse homem ficou por quase 40 anos vinculado à Irmandade, como irmão. Nos registros de atas localizados para o período de sua permanência na associação religiosa, percebemos que sua assinatura constava de próprio punho, indicando ter domínio das letras. Além disso, assinou por outros irmãos que não tinham conhecimento da escrita. Para o ano de 1897, assumiu como secretário, função importante de registro das atas da Irmandade e em 1900 foi eleito para juiz de São Benedito, um dos cargos mais importantes na associação; ainda em 1905 era consultor. Consultar: Livro Ata 3 (1875-1905) - Transcrição realizada pela professora Ma. Michelle Maria Stakonski Cechinel. Acervo da Irmandade Beneficente de Nossa Senhora do Rosário e São Benedito.

29 Jornal A Republica, Florianópolis, 15 de maio de 1920, ano XV, número 479. Acervo da Hemeroteca Digital da Biblioteca Nacional. Disponível em: <http://memoria.bn.br/DocReader/DocReader.aspx?bib= 711497x\&PagFis=15124\&Pesq=>. Acesso em: 15 nov. 2016.

30 Jornal A Republica, Florianópolis, 16 de maio de 1920, ano XV, número 480. Acervo da Hemeroteca Digital da Biblioteca Nacional. Disponível em: <http://memoria.bn.br/DocReader/DocReader.aspx?bib= 711497x\&PagFis=15124\&Pesq=>. Acesso em: 15 nov. 2016.

31 Jornal A Republica, Florianópolis, 15 de maio de 1920, ano XV, número 479. Acervo da Hemeroteca Digital da Biblioteca Nacional. Disponível em: <http://memoria.bn.br/DocReader/DocReader.aspx?bib= 711497x\&PagFis=15124\&Pesq=>. Acesso em: 15 nov. 2016. 
Izabel Falcão ${ }^{32}$, aluna do Colégio Coração de Jesus, que recitou uma poesia, e, finalizando, o poeta Araujo Figueiredo recitou uma poesia sua inédita, dedicada a Cruz e Souza ${ }^{33}$. Figueiredo era contemporâneo de Cruz e Souza e amicíssimo do poeta falecido.

O poema produzido e recitado pelo intelectual foi localizado, na íntegra, na folha especial produzida por Ildefonso Juvenal para arrecadação de fundos para a Escola Cruz e Souza. $\mathrm{Na}$ Batalha da Vida ${ }^{34}$, o poema de Araujo Figueiredo fora muito aplaudido. O tom da obra era de lamento, visto a perda tão precoce do jovem poeta, vitimado pelo racismo em vida e pelo descaso social que Ihe causara a morte. A vida de Cruz e Souza, intensa obra, ao mesmo tempo palco de sofrimento e racismo, estava ali exposta naqueles versos do amigo Figueiredo. A trajetória dos pais, ex-escravizados, um operário pedreiro e uma lavadeira que envidaram esforços em alfabetizar os filhos e inseri-los na escola, também compôs letra nessas estrofes da luta de Cruz e Souza.

Não à-toa, a memória ainda recente na cidade e nos espaços, da vida e obra de Cruz e Souza, fazia vivas às necessidades de relembrá-lo em eventos, solenidades, retratos, versos e prosas diversas. Os versos trazem à tona a "prisão" vivenciada pelo poeta, da qual nunca se libertaria, afinal a cor era marca que sempre carregaria. No entendimento do poeta amigo de Cruz e Souza, o preconceito o levara à "masmorra". A homenagem, bastante carregada de adjetivos fortes para expressar uma vida triste, pouco enfatiza a vibrante obra do autor para além dos "sofrimentos da raça".

\section{Considerações Finais}

Realizar abordagens analíticas a respeito da imprensa negra requer compreender intenções e possibilidades de seus produtores no período em questão. Diferentes territórios negros foram reconfigurados ante políticas reformistas e urbanizadoras na capital catarinense, processo que implicou também em reformulações elaboradas por

\footnotetext{
${ }^{32}$ Pelo sobrenome, provavelmente, a menina Maria Izabel era parente do sócio fundador e membro da diretoria do Centro Cívico e Recreativo José Boiteux.

33 Ibidem.

${ }^{34}$ XXIX de Maio, Florianópolis, 29 de maio de 1920, número único. Em benefício da escola noturna Cruz e Souza. Organizada por ILDEFONSO JUVENAL.
} 
ressignificados por seus pertencentes, algumas figuras ativas em Florianópolis e que marcaram também a construção de visibilidades almejadas por muitos homens e mulheres agremiadas merecem destaque, como Antonieta e Leonor de Barros, Trajano Margarida, Ildefonso Juvenal da Silva e Demerval Cordeiro, que atuaram política e educacionalmente para criar possibilidades de ascensão social a descendentes de africanos nas primeiras décadas da República.

Articulados em jornais, espaços políticos, constituindo escolas, centros cívicos e recreativos e ministrando curso primário, propunham a educação como forma de ascensão social e de melhores condições de vida. Esses personagens, diante dos empecilhos impostos pela Academia Catarinense de Letras à participação de mulheres e de descendentes de africanos, fundaram diferentes associações ao longo das primeiras décadas do século XX, dentre elas o Centro Catarinense de Letras. Articulando saberes letrados e vivências embebidas em memórias africanas, pautaram demandas e projetos político-sociais que consideravam importantes para o período.

O alcance da imprensa negra ainda carece de elementos capazes de indicar sua amplitude, tanto em termos de acesso de leitores aos periódicos quanto em virtude de ideias veiculadas e suas repercussões. Mesmo no caso de integrantes de associações, centros literários, clubes recreativos, seriam todos os associados leitores de jornais? Ou pretendia-se que fossem? No entanto, apesar de questões em aberto, compete ressaltar que tais registros, considerados importantes por um grupo de intelectuais de origem africana, sugerem formas distintas de combate ao racismo, permitindo inferir que esse grupo de intelectuais autointitulados homens de cor optou por utilizar as letras como armas na luta contra uma sociedade pós-Abolição marcadamente racista, excludente e embebida em ideais de progresso onde nem todos seriam inseridos. 


\section{Referências}

ANTONACCl, Antonieta Martines. Memórias ancoradas em corpos negros. $2^{\mathrm{a}}$ ed. rev. e ampl. São Paulo: EDUC, 2015.

CALLADO, Petrarcha. Poeta do povo. A Gazeta, Florianópolis, 16 de janeiro de 1945.

CARDOSO, Fernando Henrique; IANNI, Octávio. Cor e mobilidade social em Florianópolis. São Paulo: Cia. Ed. Nacional, 1960.

CARDOSO, Paulino de Jesus Francisco. A luta contra a apatia: estudo sobre a instituição do movimento negro antirracista na cidade de São Paulo (1915-1931). Itajaí: Casa Aberta, 2012.

CARDOSO, Paulino de Jesus Francisco. Negros em Desterro: as experiências das populações de Desterro na segunda metade o século XIX. Itajaí: Casa Aberta, 2008.

CONNERTON, Paul. Como as sociedades recordam. $2^{\mathrm{a}}$ ed. Oeiras (Portugal): Celta Editora, 1999.

CRUZ, Heloisa de Faria; PEIXOTO, Maria do Rosário da Cunha. Na oficina do historiador: conversas sobre história e imprensa. Projeto História, São Paulo, n. 35, p. 253-270, dez., 2007.

DALLABRIDA, Norberto. A fabricação escolar das elites: o Ginásio Catarinense na Primeira República. Florianópolis: Cidade Futura, 2001.

DOMINGUES, Petrônio. “Um desejo infinito de vencer”: o protagonismo negro no pósabolição. Revista Topoi, v. 12, n. 23, jul./dez., p. 118-139, 2011.

FRANCISCO, Flavio Thales Ribeiro. O novo negro na diáspora: modernidade afroamericana e as representações sobre o Brasil e a França no jornal Chicago Defender (19161940). São Paulo: Intermeios; Fapesp, 2016.

GARCIA, Fábio. Intelectuais negros no pós-abolição: associativismo negro em Florianópolis (1915-1925). Anais Eletrônicos ANPUH. Fortaleza, 2011. Disponível em: http://www.snh2011.anpuh.org/site/anaiscomplementares.

GARCIA, Fábio. Negras pretensões: a presença de intelectuais, músicos e poetas negros nos jornais de Florianópolis e Tijucas no início do século XX. Florianópolis: Umbutu, 2007.

GOMES, Flávio. Negros e política (1888-1937). Rio de Janeiro: Jorge Zahar, 2005. 
GUIMARÃES, Antônio Sérgio Alfredo. Racismo e Antirracismo no Brasil. 3 a ed. São Paulo: Editora 34, 2009.

PEREIRA, Lucésia. Florianópolis, década de trinta: ruas, rimas e desencantos na poesia de Trajano Margarida. Dissertação (Mestrado em História) - Universidade Federal de Santa Catarina (UFSC). Florianópolis, 2001.

PINTO, Regina Pahim. O movimento negro em São Paulo: luta e identidade. Ponta Grossa: Editora UEPG; São Paulo: Fundação Carlos Chagas, 2013.

RASCKE, Karla Leandro. Entre a caneta e o pandeiro: letras e enredos de agremiações afrodescendentes em Florianópolis-SC (1920 a 1950). Tese (Doutorado em História) Pontifícia Universidade Católica de São Paulo (PUC-SP). São Paulo, 2018.

RASCKE, Karla Leandro. Intelectuais negros: escritos de Trajano Margarida em Florianópolis (1915-1946). In: SEMINÁRIO EDUCAÇÃO, RELAÇÕES RACIAIS E MULTICULTURALISMO (SEREM), VI, 2017, Florianópolis. Anais... Florianópolis: UDESC, 2016. v. 1. p. 354-366.

SANTOS, André Luiz. Do mar ao morro: a geografia da pobreza urbana em Florianópolis. 2009. Tese (Doutorado em Geografia) - Universidade Federal de Santa Catarina (UFSC). Florianópolis, 2009.

SILVEIRA, Carlos Eduardo. “Orgulho-me de ser homem de cor": Ildefonso Juvenal da Silva e a luta pelo reconhecimento (início do século XX). 2015. Monografia (Graduação em História) - Universidade do Estado de Santa Catarina (UDESC). Florianópolis, 2015.

TAYLOR, Diana. $\mathbf{O}$ arquivo e o repertório: performance e memória cultural nas Américas. Tradução de Eliana Lourenço de Lima Reis. Belo Horizonte: UFMG, 2013.

THIAGO, Arnaldo. História da Literatura Catarinense. Florianópolis: Imprensa Oficial do Estado de Santa Catarina, 1957. 
Recebido em 01/04/2018 Aprovado em 19/07/2018

Universidade do Estado de Santa Catarina - UDESC

Programa de Pós-Graduação em História - PPGH

Revista Tempo e Argumento Volume 10 - Número 25 - Ano 2018 tempoeargumento@gmail.com 